\title{
The Concept of Independent Learning Viewed from the Perspective of Higher Order Thinking Skills (HOTS)
}

\author{
Enny Nurcahyawati ${ }^{1}$, Zulkarnain Alfisyahrin ${ }^{2}$ \\ \{ennienurcahya@gmail.com ${ }^{1}$, alregar_zas@yahoo.com ${ }^{2}$ \} \\ Universitas Indraprasta PGRI, Jakarta, Indonesia ${ }^{1}$, Institut Bisnis Muhammadiyah Bekasi, Indonesia ${ }^{2}$
}

\begin{abstract}
Learning aims to increase the level of thinking, so that correct behavior can be realized. If it is associated with high-level thinking, then the implementation of independent learning is not only intended to transfer knowledge from teachers to students, but also encourages students to be able to solve problems and try to improve knowledge in certain situations that are completely new. The method used by library research that is able to develop advanced thinking skills through an open approach is very possible. An open approach can inspire students to be trained and familiar with critical, logical, creative thinking, and oriented to reasoning and problem solving. Meanwhile, in decision making there must be problem solving which includes analysis, evaluation, and manufacture activities. Therefore, the open method is very good in the learning process and can support The Development Of Advanced Thinking Skills Or High Order Thinking Skills (HOTS).
\end{abstract}

Keywords: free learning, higher order thinking (Higher Order Thingking Skills-HOTS)

\author{
Konsep Merdeka Belajar Ditinjau dari Perspektif Berpikir Tingkat Tinggi \\ (Higher Order Thinking Skills)
}

\begin{abstract}
Abstrak. Pembelajaran bertujuan meningkatkan taraf berpikir, sehingga perilaku yang benar dapat terwujud. A dikaitkan dengan berpikir tingkat tinggi (high-level thinking), maka pelaksanaan pembelajaran mandiri bukan hanya dimaksudkan untuk sekadar transfer ilmu dari guru kepada siswa, namun juga mendorong siswa agar dapat memecahkan masalah serta berupaya meningkatkan ilmu dalam situasi tertentu yang sama sekali baru. Metode yang dilakukan penelitian kepustakaan yang mampu mengembangkan keterampilan berpikir tingkat lanjut melalui pendekatan terbuka sangat memungkinkan. Pendekatan terbuka dapat menginspirasi siswa untuk terlatih dan terbiasa dengan berpikir kritis, logis, kreatif, dan berorientasi pada penalaran dan pemecahan masalah. Sementara dalam pengambilan keputusan harus ada pemecahan masalah yang meliputi kegiatan analisis, evaluasi, dan pembuatan. Karenanya, metode terbuka sangat baik dalam proses belajar dan dapat mendukung pengembangan kecakapan berpikir lanjutan atau high order thinking skills (HOTS).
\end{abstract}

Kata kunci: belajar bebas, berpikir tingkat tinggi 


\section{Pendahuluan}

Menteri pendidikan dan kebudayaan Bapak Nadiem Makarim menegaskan terkait edaran Kemdikbud No 1/2020 tentang merdeka belajar, khususnya mengenai ujian sekolah berstandar nasional atau dikenal sebagai (USBN), ujian nasional (UN) dan rencana pelaksanaan pembelajaran (RPP) serta peraturan penerimaan peserta didik baru (PPDB) ber-zonasi. Kenyataannya, banyak orangtua dan para guru yang mempengaruhi jalanya proses pembelajaran di sekolah [1]. Untuk diketahui, pemerintah Indonesia selalu memberikan perhatiannya pada sektor pendidikan. Hal itu dibuktikan dengan dikeluarkannya policy pemerintah pada lingkup pendidikan, diawali dengan rancangan wajib belajar dan program beasiswa yang diperuntukkan bagi masyarakat tidak mampu.

Untuk itulah pemerintah mencoba mencanangkan program baru untuk mengejar ketertinggalan daripada negara-negera lain. Program Merdeka Belajar menjadi sasaran pembelajaran yang berfokus kepada peningkatan mutu manusia. Merdeka belajar tak lain awal mula dari gagasan mengamandemen sistem pendidikan nasional yang terkesan repetitive dan tidak berkembang. Oleh karena itu, Merdeka Belajar dijadikan satu rencana pembelajaran yang akan menjadikan lingkungan belajar di sekolah lebih menyenangkan, baik bagi siswa maupun guru. Tentu hal ini berkaitan dengan Merdeka Belajar yang dicanangkan Nadiem Makarim. Agar Merdeka Belajar dapat terlaksana, ada baiknya pendidik mengubah sudut pandang pendidikan dengan kacamata High Order Thingking Skills (HOTS). Kecakapan inilah yang biasa dikenal dengan berpikir tingkat tinggi (HOTS) [2]. Berpikir tingkat jika dikaitan dengan kebijakan Merdeka Belajar, harapannya adalah pendidikan mempunyai tujuan yang pasti. Harapan lebih jauh adalah pendidikan di wilayah Indonesia bisa berkembang lebih maju, bermutu, serta sesuai dengan harapan seluruh lapisan masyarakat juga sejalan dengan amanat UUD 1945.

\section{Metode}

Jenis penelitian penulisan ini menggunakan penelitan deskriptif dalam pendekatan kualitatif. Pendekatan Kualitatif sendiri dijelaskan oleh Sugiyono [3] sebagai alat untuk meneliti kondisi objek secara alami. Pada akhirnya akan menggunakan analisis data yang mengedepankan penalaran dan hasil akhir penelitian yang diperoleh akan menghasilkan mana atau data yang sesungguhnya secara menyeluruh. Data dalam penelitian kualitatif dianggap nyata karena berasal dari suatu nilai yang diperoleh dalam suatu penelitian. Sedangkan jenis penelitian yang digunakan adalah Library Reseacrh. Atau dapat disebut sebagai studi pustaka yang memanfaatan data sekunder. Zed [4] menjelaskan bahwa studi pustaka meiliki fungsi lebih dari sekadar membantu sebuah penelitian. Secara sederhana, dengan menggunakan sudi pustaka, peneliti dapat memperoleh data hanya denga menggunakan data sekunder tanpa harus melakukan penelitian secara langsung.

\section{Hasil dan Pembahasan}

Proses pembelajaran merupakan unsur dari tatanan pendidikan yang dapat melandasi kesuksesan proses belajar seorang individu. Idealnya sebuah pendidikan cenderung 
menekankan kepada tahapan serta keluaran. Kenyataannya, efektivitas belajar seorang individu yang dinggap baik belum tentu dapat dikatakan sebagai tahapan pembelajaran yang baik. Apabila melakukan proses pembelajaran yang baik, maka keluaran yang didapatkan cenderung lebih baik. Perjalanan sebuah proses pembelajaran adalah fasilititas yang ada di dalam suatu pendidikan, yakni meliputi proses dalam mendapatan ilmu pengetahuan, menguasai keahliannya, sifat, serta terbentuknya sikap [5].

Kenyataannya, pada proses pembelajaran di kelas, apabila tidak memanfaatkan buku teks maka akan muncul beberapa kesalahan serta kealfaan pada saat guru melakukan proses pembelajaran. Kondisi ini tentu dapat menjadi hambatan bagi seorang guru dalam mengelola kalimat, berimajinasi, dan melakukan kreatifitas pada saat melakukan pembelajaran. Permasalahan ini dapat berimbas juga kepada para siswa, khususnya dalam hal berkreasi dan berimajinasi. Buku teks dalam proses ini berfungsi untuk membimbing serta membantu siswa dalam berimajinasi, berpikir, dan berespresi, namun siswa juga butuh rasa merdeka di dalam menjalankan proses belajar-mengajar. Konsep Pendidikan Merdeka Belajar ini yang diperlukan untuk meningkatkan kemampuan berpikir dan kreatifitas siswa.

Semenjak Menteri Pendidikan dan Kebudayaan mencanangkan program Merdeka Belajar, maka pendidik perlu mulai memahami bahwa kemerdekaan guru dan kemerdekaan belajar, akan memiliki interseks dengan berbagai unser, baik yang terjadi di dalam ataupun di luar lingkungan sekolah. Di antaranya, memberikan kemerdekaan kepada siswa ketika melakukan proses belajar mengajar. Dalam merdeka belajar, kemerdekaan sudah seharusnya melekat kepada individu yang melakukan proses belajar, baik yang berstatus anak maupun orang dewasa, termasuk di dalamnya semua pihak yang terlibat

Merdeka Belajar merupakan penghayatan kepada kemerdekaan berpikir. Dalam hal ini, yang utama sekali harus diperhatikan adalah pemahaman guru akan esensi kemerdekaan berpikir. Esensi dari kemerdekaan berpikir ini harus dimiliki oleh guru lebih dulu. Karena, apabila guru belum memahami esensi tersebut, ada kemungkinan peserta didik juga tidak memahaminya. Gagasan mengenai kemerdekaan bukan sekadar kepatuhan maupun perlawanan, tetapi juga suatu kondisi yang penting dan harus diperjuangkan. Namun, terdapat fakta menyedihkan dari pengembangan guru, yakni sebagian besar guru cenderung dipersalahkan bukan didengarkan. Seorang guru dapat dikatakkan pintu gerbang dalam pendidikan. Di dalam kalimat yang sesungguhnya, bukanlah kalimat lengkap. Pintu gerbang kadangkala selalu diartikan sebagai jalan keluar segala persoalan. Bahkan guru di kelas seringkali harus menghadapi beberapa peserta didik yang tidak siap belajar dan kurang berkonsentrasi. Siswa mempunyai tingkat aktivitas yang terlalu padat dikarenakan sudah terbiasa berada di dalam kepadatan atau tidak menjalani peruntungan. Kondisi ini umumnya terjadi karena adanya ancaman atau hukuman berlebihan, yang diakibatkan oleh kondisi ekonomi dan kegagalan di dalam keluarga yang berdampak pada kurangnya fasilitas pendidikan. Pada akhirnya, guru dibebankan oleh harapan yang besar sebagai harapan dapat merubah kondisi tersebut [6].

Gagasan dasar Merdeka Belajar ini ada karena terdorong kemauannya untuk mewujudkan lingkungan belajar tanpa adanya beban oleh pencapaian angka atau nilai tertentu. Ada empat policy Pendidikan Nasional Merdeka Belajar

Tabel 1. Policy Pendidikan Nasional 'Merdeka Belajar'

USBN menjadi penilaian Penilaian kemampuan peserta didik berupa tes tertulis dan oleh pihak guru dan melihat hasil tersebut secara keseluruhan. Selain itu, tenaga sekolah pendidik serta sekolah dinilai dapat lebih merdeka, khususnya pada saat memberikan penilaian atas hasil pembelajaran para peserta didik. 


\begin{tabular}{ll}
\hline $\begin{array}{l}\text { UN diubah menjadi } \\
\text { penilaian kemampuan } \\
\text { minimum } \\
\text { pengamatan karater }\end{array}$ & $\begin{array}{l}\text { Penguasan materi setiap mata pelajaran di setiap kurikulum } \\
\text { tidak menjadi tolak ukur UN. Untuk itu, UN cenderung } \\
\text { dimanfaatkan sebagai pemetaan kemampuan minimal yang } \\
\text { melputi kemampuan membaca dan menghitung dari setiap } \\
\text { peserta didik, hal ini ditujukan untuk memperkukuh } \\
\text { pengaplikasian metode pengajaran yang akan diukur oleh PISA } \\
\text { serta TIMSS. Metode ini sudah dilakukan disekolah, khususnya } \\
\text { kelas 4,8, dan 11. }\end{array}$ \\
\hline $\begin{array}{l}\text { Rencana Pelaksanaan } \\
\text { Pembelajaran (RPP) }\end{array}$ & $\begin{array}{l}\text { Dalam hal ini, setiap guru memiliki wewenang untuk memilih, } \\
\text { merancang, melakukan inovasi, dan memanfaakan format RPP } \\
\text { atas prakarsa serta pengembangan selama prosesnya. }\end{array}$ \\
\hline $\begin{array}{l}\text { Sistem Zonasi PPDB } \\
\text { dilakukan secara lebih } \\
\text { mudah }\end{array}$ & $\begin{array}{l}\text { Langkah yang diambil untuk memperbaiki adanya ketimpangan } \\
\text { akses serta mutu yang terjadi di berbagai daerah, dapat } \\
\text { merancang standar PPDB diantar daerah. Rancangan ini dapat } \\
\text { terbagi menjadi beberapa bagian, seperti jalur zonasi (50\%), } \\
\text { jalur afirmasi (15\%), jalur perpindahan (5\%), dan jalur prestasi } \\
\text { atau lainnya (0-30\%) pada setiap wilayah. Untuk menetapkan } \\
\text { jalur zonasi, setiap daerah atau wilayah dapat menyesuaikan } \\
\text { populasi dari masyarakat. }\end{array}$
\end{tabular}

Sumber: Kemendidbud dikutip dari Seminar Nasional Pasca Sarjana UNJ [7]

Paparan konsep regulasi merdeka belajar telah disampaikan oleh Menteri Pendidikan dan Kebudayaan Bapak Nadiem Makarim di atas menunjukkan adanya kesamaan dengan konsep Merdeka Belajar dengan HOTS. Kesamaannya adalah adanya pendidikan yang menjadikan Indonesia bisa mejadi lebih maju, bermutu, dan sesuai dengan harapan semua masyarakat.

Pada lingkup dunia kependidikan, pembagian tingkatan penalaran/pikiran disebut juga taksonomi. Pada era 21, taksonomi selalu menjadi referensi di dalam dunia Pendidikan. Dalam karya Anderson dan Krathwohl [8], hal tersebut umumnya dikenal sebagai penalaran tingkat tinggi.

Dalam konsep HOTS, menurut Benjamin S Bloom, terdapat enam tingkatan kemampuan bernalar manusia, yaitu

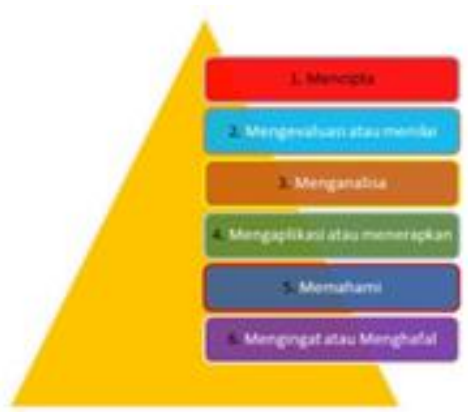

Gambar 1. Tingkat kemampuan Siswa (Bloom \& etc, 1956) 


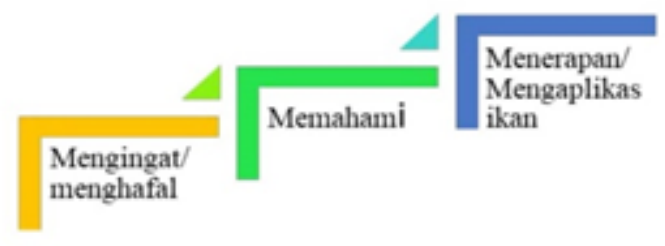

Gambar 2. Tingkat Kemampuan Keterampilan Berpikir Tingkat Rendah

Berpikir atau penalaran tingkat tinggi adalah kesanggupan di dalam menghubungkan (connect), memanipulasi, serta mengaplikasikan ilmu pengetahuan dengan pemahaman (empiris) yang dimilikinya secara lebih kritis dan juga kreatif di dalam membuat sebuah keputusan guna menyelesaikan permasalahan pada situasi dan kondisi baru. Jika dilihat dari bagan di atas, maka klasifikasi pada tingkat kemampuan siswa dapat dinyatakan sebagai pemikiran dengan tingkat yang rendah. Proses pembelajaran pada Tingkat kemampuan Keterampilan Berpikir Tingkat Rendah selalu menggunakan buku teks dan pendidik selalu mendampingi. Siswa belum bisa dilepas sendiri karena tingkat kemandiriannya juga masih rendah. Sedangkan pada tingkat penalaran yang lebih tinggi, tidak terlalu banyak memerlukan buku teks, akan tetapi lebih kepada berpikir dan mencari serta menganalisa dengan melihat berbagai hal dari persfektif yang berbeda.

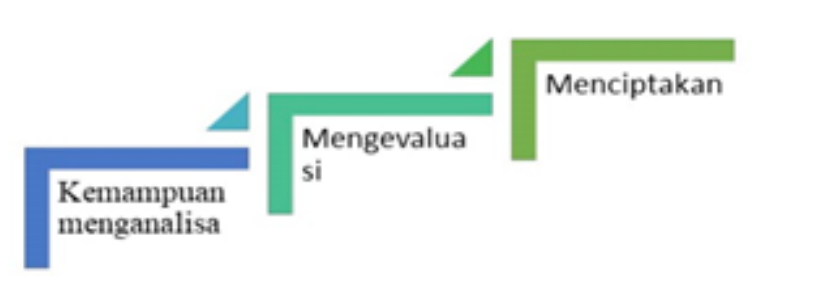

Gambar 3. Tingkat Keterampilan Tingkat Tinggi

Pada gambar di atas inilah siswa belajar secara mandiri, sejalan dengan apa yang dicanangkan Menteri Pendidikan dan Kebudayaan, yaitu merdeka belajar dengan keahlian dalam berpikir Tingkat Tinggi. High Order Thinking Skills (HOTS) adalah perkembangan tahapan berpikir siswa pada tingkatan kognitif (proses berpikir dengan penyelesaian masalah) yang semakin tinggi, berkembang dengan bermacam gagasan dan model kognitif serta taksonomi pembelajaran, yakni meliputi model problem solving, taksonomi Bloom, juga taksonomi pembelajaran dan pengajaran serta penilaian [9].

Menelisik tujuan konsep merdeka belajar di sini adalah dengan melihat sudut pandang ekstrinsik siswa (luar diri) menjadi lebih dominan ketika mengambil sebuah keputusan. Begitu juga sebaliknya, ketika mereka mampu menjabarkan alasan kenapa harus menggunakan masker ketika hendak ke luar dari rumah, harus mencuci tangan atau menggunakan hand sanitaizer pada saat masa wabah/pandemi corona (Covid-19) ini; untuk apa, untuk menghindari penularan virus tersebut kepada kita dari penderita yang kita tidak tahu dimana virus itu bertebarnya. Lalu, ketika mereka diminta menjaga jarak dari satu kepada yang lainnya. Tingkat penalaran siswa yang seperti itu dinyatakan sudah pada tahap mampu menganalisa sendiri apa tindakan yang perlu dilakukan dalam sebuah situasi. Mereka tidak hanya sekadar mengikuti perintah, tetapi 
mempunyai kesadaran penuh dan pemahaman yang tinggi akan suatu hal. Kategori tingkat penalaran ini sudah termasuk di dalam tingkatan penalaran/berpikir tinggi.

High order thinking skills mencakup berbagai kemampuan, seperti memecahkan/penyelesaikan masalah (problem solving), kemampuan berpikir secara kreatif (creative thinking), efektif, berpikir/penalaran kritis (critical thinking), keahlian dalam berargumentasi (reasoning), dan mampu merencanakan sebuah keputusan (decision making). Penalaran tingkat/level tinggi termasuk berpikir kritis (critical thinking), logis, reflektif, metakognitif, dan kreatif, menurut Newman dan Wehlage dalam Widodo \& Kadarwati [10]. Menurut Wiederhold dalam Suyitno [11] pola pemecahan persoalan yang dilihat sebagai pola pembelajaran sehingga dapat menaikan kemampuan peserta didik untuk dapat berpikir/ memiliki penalaran tinggi. Pola menyelesaikan persoalan dengan berpikir/penalaran tingkat tinggi bisa membawa peserta didik kepada pengalaman (empiris) dalam menerapkkan ilmu pengetahuan dan keterampilan dengan baik, penemuan model pemecahan. Kemampuan komunikasi yang baik membuat belajar terasa lebih bermakna.

Konsep Merdeka Belajar dengan kemampuan berpikir tingkat tinggi sesungguhnya mementingkan kepada sistem pembelajaran yang banyak mengarah guna menjawab permasalahan dari perspektif peserta didik. Sedangkan kegiatan pembelajaran berfokus kepada keterampilan/mahir berpikir secara kritis (critical thinking), menganalisis, menganalogikan, mengeneralisasi, memperkirakan, serta mengorganisasikan pandangan yang berbeda. Pelaksanaan evaluasi Merdeka Belajar lebih menekankan kepada metode penyusunan bermakna secara dinamis dengan mengimplikasi keahlian terpadu dengan memakai persoalan pada kondisi sebenarnya.

Proses penilaian adalah menggali munculnya pola pikir yang berbeda, tumpukan pemecahan masalah tanpa mengharapkan jawaban yang tepat, karena pada faktanya siswa tidak memiliki jawaban yang salah. Hanya ada masalah dengan pendidik yang salah. Standar kompetisi adalah salah satu unsur integral dari pembelajaran, meliputi pemberian beban yang memerlukan akivitas belajar yang memiliki makna dan penerapan dari apa yang sudah diperoleh dalam pengaturan dunia nyata. Penilaian lebih menekankan pada keterampilan proses kelompok[6]. Sistem merdeka belajar bernalar atau berpikir tingkat tinggi sangat diyakini mampu menjadi pilar dari sumber daya manusia (SDM) yang meiliki kualitas dan kuantitas di negara Indonesia.

\section{Simpulan}

Konsep Merdeka Belajar mengadopsi pemikiran tingkat tinggi yang dapat terwujud manakala semua siswa berpartisipasi penuh dengan semua pengetahuan yang mereka miliki untuk dapat mengubahnya. Peserta didik diharapkan dapat merubah ilmu pengetahuan serta menghasilkan sesuatu hal baru juga lebih bermakna. Lewat Merdeka Belajar dengan HOTS, siswa mampu membedakan ide secara jelas dan nyata. Siswa juga dapat berargumentasi dengan baik. Tidak hanya itu, siswa pun mampu memecahkan suatu masalah dan menjelaskan secara detail persoalan sebenarnya. Terakhir, siswa mampu memberikan pendapatnya dengan lebih jelas. 


\section{Referensi}

[1] Kemendikbud. Mendikbud Tetapkan Empat Pokok Kebijakan Pendidikan "Merdeka Belajar” 2019. https://www.kemdikbud.go.id/main/blog/2019/12/mendikbud-tetapkanempat-pokok-kebijakan-pendidikan-merdeka-belajar.

[2] Dinni HN. HOTS (High Order Thinking Skills) dan kaitannya dengan kemampuan literasi matematika. Prism. Pros. Semin. Nas. Mat., vol. 1, Semarang: Universitas Negeri Semarang; 2018, p. 170-6.

[3] Sugiyono. Memahami penelitian kualitatif. Bandung: CV. Alfabeta; 2010.

[4] Zed M. Metode Penelitian Kepustakaan. Jakarta: Yayasan Obor Indonesia; 2004.

[5] Halitopo M. Implementasi Merdeka Belajar dalam Buku Teks Bahasa Inggris untuk SMK. Semin. Nas. Implementasi Merdeka Belajar Berdasarkan Ajaran Tamansiswa, vol. 1, Yogyakarta: Pascasarjana Pendidikan Universitas Sarjanawiyata Tamansiswa; 2020, p. 54-61.

[6] IntenNews. Menakar Konsep “Merdeka Belajar.” Inten News 2020.

[7] Rosyidi U. Merdeka Belajar: Aplikasinya Dalam Manajemen Pendidikan \& Pembelajaran di Sekolah. Semin. Nas. “Merdeka Belajar dalam mencapai Indones. Maju 2045,” Jakarta: Universitas Negeri Jakarta; 2020.

[8] Anderson LW, Krathwohl DR. A taxonomy for learning, teaching, and assessing: A revision of Bloom's taxonomy of educational objectives. Longman; 2001.

[9] Saputra H. Pengembangan Mutu Pendidikan Menuju Era Global: Penguatan Mutu Pembelajaran dengan Penerapan HOTS (High Order Thinking Skills). Bandung: Smile's Publishing; 2016.

[10] Widodo T, Kadarwati S. Higher order thinking berbasis pemecahan masalah untuk meningkatkan hasil belajar berorientasi pembentukan karakter siswa. Cakrawala Pendidik 2013;5. https://doi.org/10.21831/cp.v5i1.1269.

[11] Suyitno A. Handout Kuliah Teori Pembelajaran Matematika. Semarang: Jurusan Matematika FMIPA UNNES; 2006. 